\title{
Physiological studies on growth promotive effects of the endophytic fungus Piriformospora indica on some crop plants
}

a- Effects on growth and physiological performance.

\author{
Ahmed M.A. Mazen, Osman M.O. El Maghraby and Shereen Abd Elmohsen Ebaid Nasr* \\ Botany Department, Faculty of Science, Sohag University, Sohag 82534, Egypt
}

Rec. 6 Oct, 2014 Accept. 17 Dec, 2014

\begin{abstract}
The influence of root endophyte fungus Piriformospora indica on some crop plants was studied under pot conditions. The investigated plants were Vicia faba, Lupinus termis, Arachis hypogaea and Hibiscus sabdariffa. The presence of root endophyte fungus Piriformospora indica resulted significant increasing in plant biomass i.e. fresh, dry weight and length for both root and shoot compared with the non-colonized plants for all tested plants. Photosynthetic pigments content in leaves plant tissue appeared significant increasing in colonized plants compared to non-colonized plants in all tested plants, increasing ratio of total photosynthetic pigments were $21 \%, 50 \%, 16 \%$ and $13 \%$ in cases V. faba, L. termis and A. hypogaea, $H$. sabdariffa, respectively. The soluble proteins of various tested plants exhibited higher contents in colonized plants by $P$. indica than those of non-colonized plants. Moreover, enhance water relations where transpiration rate showed a significant increase in colonized plants by $P$. indica. Enhancement percentages were $14 \%, 64 \%, 121 \%$ and $92 \%$ in V. faba, L. termis, A. hypogaea and H. sabdariffa, respectively. Sodium content in colonized plants appeared decreasing content compered to non-colonized plants. Decreasing ratios were $16 \%, 10 \%, 13 \%$ and $20 \%$ in $V$. faba, L. termis, A. hypogaea and H. sabdariffa, respectively. Furthermore, calcium content in colonized plants was better than calcium content in noncolonized plants. Where, increasing ratios were, 25\%, 40\%, 30\% and14\% in V. faba, L. termis, A. hypogaea and $H$. sabdariffa, respectively. Finally, potassium content appeared significant increasing in colonized plants $25 \%, 16 \%, 40 \%$ and $45 \%$ in V. faba, L. termis, A. hypogaea and $H$. sabdariffa, respectively compared to non-colonized plants.
\end{abstract}

Key word: Piriformospora indica, Vicia faba, Lupinus terms, Arachis hypogaea and Hibiscus sabdariffa.

\section{Introduction}

The axenically cultivable plant growthpromoting root endophyte fungus, Piriformospora indica (Hymenomycetes, Basidiomycota) is a newly described cultivable endophyte that colonizes roots (Verma, 1998). P. indica interacts with the roots of a great variety of plants, showing a positive effect on biomass production (B. Bütehorn, et al., 2000). Due to its ease of culture, this fungus provides a model organism for the study of beneficial plantmicrobe interactions and a new tool for improving plant production systems (Verma, 1998).

The most obvious effect of $P$. indica on plants is the promotion of vegetative growth, and this had been repeatedly shown with species from various plant families (P. Franken, 2012).

The endophyte promotes nutrient uptake, allows plants to survive under water, temperature and salt stress, confers (systemic) resistance to toxins, heavy metal ions and pathogenic organisms and stimulates growth and seed production

\footnotetext{
* Corresponding author:

Dr. Shereen Abd Elmohsen Ebaid Nasr

$\bowtie$ shereen.nasr1@yahoo.com
} 
(Pham et al., 2004a,b; Kaldorf et al., 2005; Sherameti et al., , 2008a,b; Vadassery et al., 2008, 2009a, b; Waller et al., 2005, 2008) The host range includes bryophytes (Aneura pinguis), pteridophytes (Pteris ensiormis), gymnosperms (Pinus halepensis), and a large number of angiosperms (Waller et al., 2005; Serfling et al., 2007).

Piriformospora indica colonizes the roots, grows inter- and intracellularly, forms pear shaped spores within the cortex and extramatrically, and does not invade the endodermis and the aerial parts of the plants (Oelmüller et al., 2009).

The extent of growth promotion is typically around $50 \%$, but significant variation exists, likely due in part to a number of environmental and experimental conditions (Franken P, 2012). Thus far, analysis has only been carried out on the influence of substrate and the timing of inoculation on growth promotion (Fakhro A., et al., 2010). Following the course of growth parameters indicated that $P$. indica promoted initial stages of plant development (Barazani et al., 2005; Rai and Varma 2005). Further on, promotion of initial stages of vegetative growth results in an earlier switch to generative stages (Barazani et al., 2005; Achatz et al. 2010; Andrade-Linares et al. 2012). Promotion of early growth stages seems to be mainly based on accelerated root development (Waller et al., 2005; Baltruschat et al. 2008), and age-dependent regulation of genes was shifted to earlier time points in $P$. indica-colonised roots (Waller et al., 2008). Promotion of root development is an interesting feature as such. Indeed, application of $P$. indica resulted in enhanced rooting of callus cultures (Varma et al., 1999) and cuttings in the production of medicinal and ornamental plants (Rai and Varma 2005; Drüge et al. 2007). Interestingly, root growth promotion can be achieved even in the absence of colonisation (Drüge et al., 2007).

It is clear that; $P$. indica has a Promotive effect on plant growth. Therefore, our objectives in this study were to determine the pattern of root colonization by this fungus and to assess its effect on the growth of four plant species: Vicia faba, Lupinus termis, Arachis hypogaea and Hibiscus sabdariffa.

\section{Materials and Methods}

The present research was carried out to explore the relationships between Piriformospora indica and four plants species, Vicia faba, Lupinus terms, Arachis hypogaea and Hibiscus sabdariffa on their growth. To reach this aim several experiments were carried out on these plants.

\section{1-Plant material:}

Seeds of four plants were obtained from the agriculture research center, Shandaweel Agriculture Research Station, Sohag, Egypt. Plants seeds were surface sterilized for $1 \mathrm{~min}$ in $75 \%$ ethanol and then washed three times by sterilized distilled water for $5 \mathrm{~min}$ for each time, then cultivated in plastic pots containing sterilized soil.

\section{2-Soil:}

The soil used in the experiments was mixture of sand/clay (2:1) which was sterilized at $180^{\circ} \mathrm{C}$ for $30 \mathrm{~min}$ in oven before culture the seeds.

\section{3-Cultivation of fungus:}

The fungus was maintained on Kafer's medium (Kafer, 1977). The fungus grew in liquid medium. The culture medium was inoculated with agar containing fungal discs and incubated at $28 \pm 2^{\circ} \mathrm{C}$ under constant shaking conditions $(100 \mathrm{rpm})$ in dark for 14 days.

\section{4-Experimental design:}

Plastic pots containing $2 \mathrm{~kg}$ soil were divided into two sets and treated as the follow ( 3 pots were used for each treatment):

a- Set one: control plants (noncolonized by $P$. indica).

b- Set two: colonized plants by $P$. indica.

Experiment was carried out in the open field greenhouse of Botany department, Faculty of science, Sohag University. Plants were carefully watered every three days with tap water. The previous design was carried out for all plant species.

After 14 days from cultivated plants, set two plants were treated by $200 \mathrm{ml}$ of $P$. indica liquid culture. Then collected all plants after 30 days and did the following experiment:

\section{5- Growth parameters:}

Four weeks after inoculation, whole plants (all species) were harvested and 
divided into roots and shoots, fresh, \& dry weights and length of each were determined.

6- Determination of photosynthetic process

6.a- Photosynthetic pigments:

The photosynthetic pigments viz, chlorophyll a, chlorophyll b and carotenoids, were determined using the spectrophotometric method recommended by Metzner et al., (1965). It was possible to determine the concentrations of the pigment fractions (chlorophyll a, chlorophyll b and carotenoids) as $\mathrm{mg} / \mathrm{ml}$ using the following equations:

Chlorophyll $\mathrm{a}=10.3 \mathrm{E}_{663}-0.918 \mathrm{E}_{644}=$ $\mathrm{g} / \mathrm{ml}$

Chlorophyll $\mathrm{b}=19.7 \mathrm{E}_{644}-3.87 \mathrm{E}_{663}=$ $\mathrm{g} / \mathrm{ml}$

Carotenoids $=4.2$ E452.5- $\quad(0.0264$ chlorophyll $\mathrm{a}+0.0462$ chlorophyll $\mathrm{b})=$ $\mathrm{g} / \mathrm{ml}$

Finally, the pigment fractions were calculated as $\mathrm{mg} / \mathrm{gm}$ fresh weight.

\section{6.b-Photosynthetic rate and intercellular $\mathrm{CO}_{2}$ :}

Leaves of control and treated plants were subjected to analyses of net photosynthetic rate (A) and substomatal $\mathrm{CO}_{2}(\mathrm{Ci})$ using $\mathrm{LCi}$ Portable Photosynthesis System.

7- Plant-water relationship parameters 7.a- Transpiration rate and stomatal conductance:

Leaves of control and treated plants were subjected to analyses of net transpiration rate (E) and stomatal conductance (Gs) using LCi Portable Photosynthesis System.

\section{7.b- Relative water content (RWC):}

The RWC stated by Slatyer in 1967, express in percentage the water content at a given time and tissue as related to the water content at full turgor:

$\mathrm{RWC}=(\mathrm{FW}-\mathrm{DW}) /(\mathrm{TW}-\mathrm{DW})$

$\mathrm{FW}=$ fresh weight

$\mathrm{TW}=$ turgid weight

DW $=$ dry weight

\section{8- Protein content and profile: \\ 8.a-Protein content:}

The soluble, insoluble and total proteins were determined according to the method adopted by Lowery et al., (1951).

\section{8.b-Protein profile :}

Electrophoresis detection of protein in plant tissue by sodium dodycle sulphate polyacrylamide gel electrophoresis (SDSPAGE) following the method described by Laemmli(1970) was used in the present study.

9- Determination of some mineralsCa, $\mathrm{Na}$, K:

Dry samples of shoots were ground into a fine powder in a micro mill and assayed for mineral ion determinations. The wet digestion method (Humphries, 1956) was used. Samples of the solution were taken for $\mathrm{Na}, \mathrm{K}$ and $\mathrm{Ca}$ determination and the data were expressed as $\mathrm{mg} \backslash \mathrm{gm}$. dry weigh.

\section{0-Statistical analysis:}

Data for all attributes were subjected to a ANOVA one-way analysis of variance and the mean values were compared with the least significance difference at 0.05 levels, with the Origin program.

\section{Results}

\section{Plant growth parameters:}

At the end of experimental period growth parameters such as fresh, dry weight and length for both root and shoot were determined, it was found that, growth of $V$. faba, L. termis, A. hypogaea and $H$. sabdariffa in the presence of $P$. indica showed significant increase compared with the non-colonized plants in both fresh and dry weights of roots and shoots for all tested plants. Moreover, the increasing ratios in the root fresh weight of colonized plants: $V$. faba, L. termis, A. hypogaea and $H$. sabdariffa were found to be $60 \%, 133 \%$ , $35 \%$ and $55 \%$, and for dry weight: $94 \%$, $66 \%, 30 \%$ and $76 \%$, respectively. Furthermore, shoot biomass enhancement in colonized plants reach to $92 \%, 16 \%, 70 \%$ and $144 \%$ for fresh weight and $140 \%, 32 \%$, $71 \%$ and $21 \%$ for dry weight, in V. faba, $L$. termis, A. hypogaea and $H$. sabdariffa, respectively. In addition, there was increase in the length of both roots and shoots, where increasing ratios of roots lengths were $30 \%$, $40 \%, 13 \%$ and $17 \%$, and shoots lengths were $12 \%, 13 \%, 30 \%$ and $0 \%$ for $V$. faba, $L$. termis ,A. hypogaea , and $H$. sabdariffa, respectively ( $c f$. Fig. 1). 


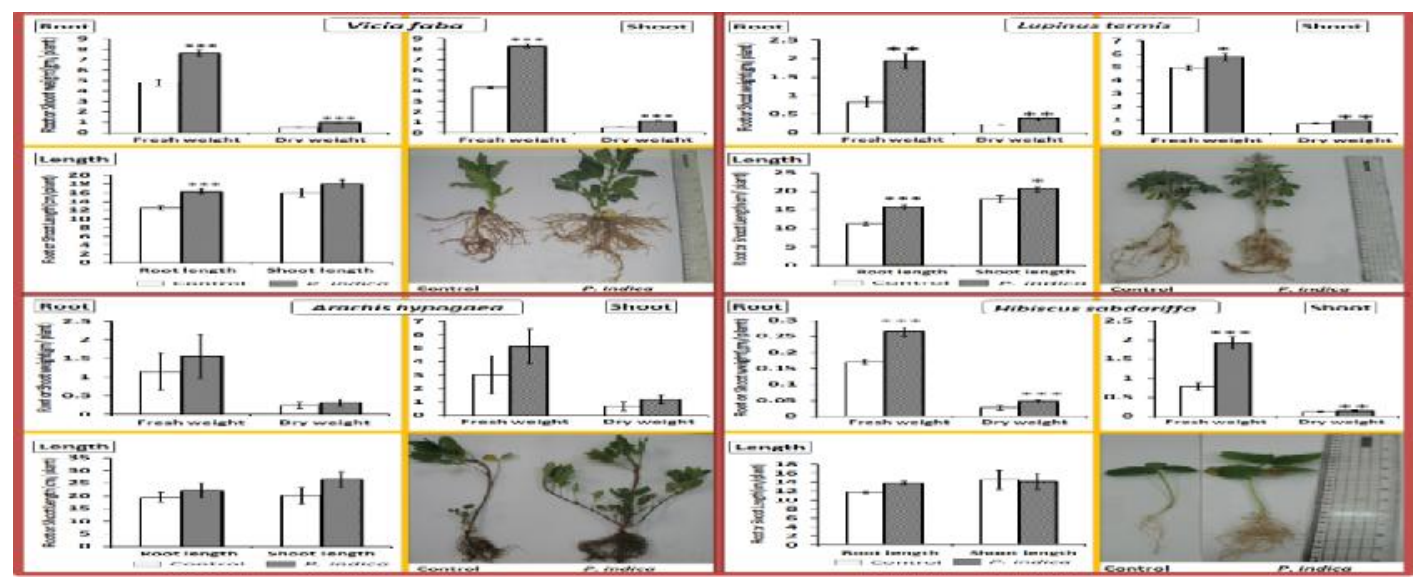

Figure 1: Effect of inoculation with $P$. indica on root and shoot fresh, dry weight and length of experimental plants. Error bar in each column equals the standard deviation from the mean. Difference is significant at $\mathrm{P}<0.05$ $(*)$, at $\mathrm{P}<0.01(* *)$, and at $\mathrm{P}<0.001(* * *)$ according the One-Way ANOVA.

\section{Photosynthesis properties:}

a-Photosynthetic pigment contents:

Observed results showed that photosynthetic pigments content in leaf plant tissue represented by chlorophyll a, chlorophyll $b$ and carotenoids appeared significant increase in colonized plants compared to noncolonized plants in all tested plants. In detail, increasing ratio in chlorophyll a content was $16 \%, 43 \%, 31 \%$ and $8 \%$, and increasing ratio in chlorophyll b content was $48 \%$, $34 \%, 13 \%$ and $28 \%$, and increasing ratio in carotenoids content was $28 \%, 75 \%, 5 \%$ and $2 \%$. In addition of these results increasing ratio of total photosynthetic pigments were $21 \%, 50 \%, 16 \%$ and $13 \%$ in cases V. faba, $L$. termis and $A$. hypogaea, $H$. sabdariffa respectively ( $c f$. Fig. 2).

b-Photosynthetic rate:
The photosynthetic rate of $V$. faba, L. termis, $A$. hypogaea and $H$. sabdariffa leaves were estimated at 6 weeks after cultivation ( $c f$. Figs. 2). The enhancement of photosynthetic pigment contents resulted in a positive changes in the photosynthetic rate. Significant increases in photosynthetic rate were recorded. These increases reached up to $28 \%, 53 \%, 50 \%$ and $46 \%$ in V. faba, L. termis, A. hypogaea and $H$. sabdariffa, respectively.

Furthermore, the intercellular $\mathrm{CO} 2$ concentration (Ci) showed non-significant increasing in cases $V$. faba, L. termis and $H$. sabdariffa while there was significant increase in case A. hypogaea in colonized plants compared to non-colonized plants ( $c f$. Figs. 2).

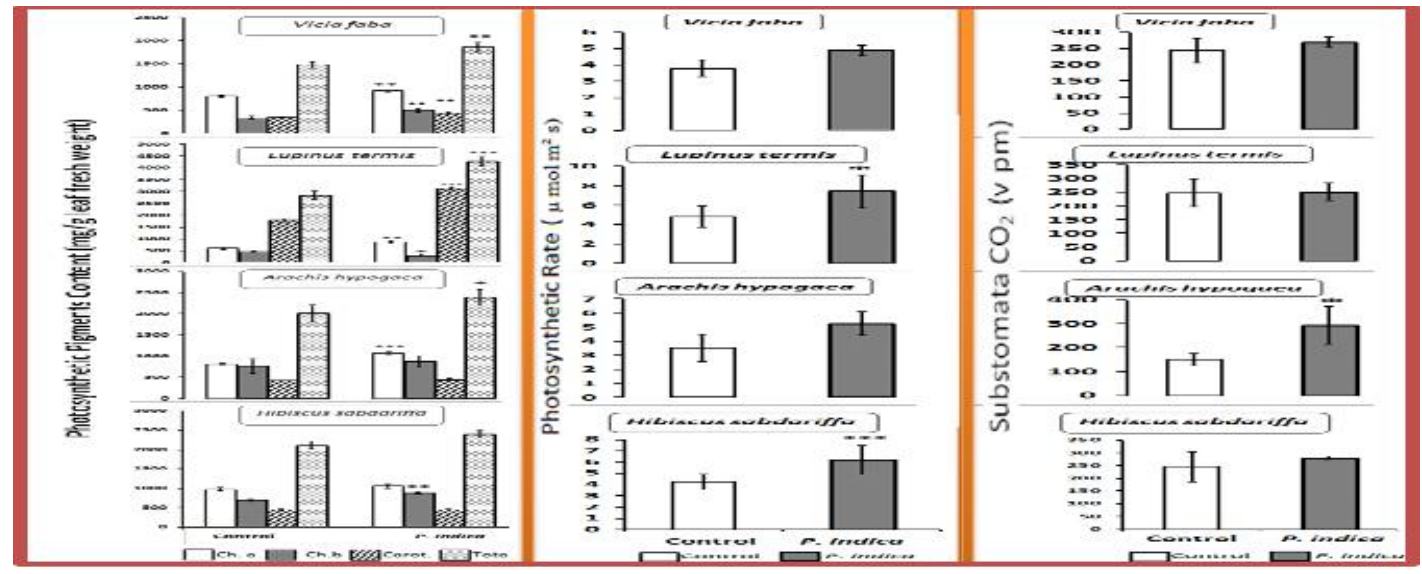

Figure 2: Effect of inoculation with $P$.indica on leaf content of photosynthetic pigments, photosynthetic rate and intercellular $\mathrm{CO}_{2}$ of experimental plants. Error bar in each column equals the standard deviation from the mean. Difference is significant at $\mathrm{P}<0.05(*)$, at $\mathrm{P}<0.01(* *)$, and at $\mathrm{P}<0.001(* * *)$ according the One-Way ANOVA.

\section{Water relations:}

Gas exchange parameters, i.e. Transpiration rate $(\mathrm{E})$ and stomatal conductance $(\mathrm{Gs})$ had been estimated in experimented plants in response to colonized by $P$. indica. Transpiration rate $(\mathrm{E})$ showed a significant 
increase in colonized plants by $P$. indica. Enhancement percentages were $14 \%, 64 \%$, $121 \%$ and $92 \%$ in V. faba, L. termis, A. hypogaea and $H$. sabdariffa, respectively ( $c f$. Fig. 3).

Moreover the process of $\mathrm{CO} 2$ assimilation was closely determined by stomatal conductance (Gs) of leaves. Results showed a variable increasing ratio in stomatal conductance process in colonized plants compared to non-colonized plants, where: $19 \%, 80 \%, 180 \%$ and $100 \%$ in V. faba, L. termis, A. hypogaea and $H$. sabdariffa, respectively (cf. Fig. 3).

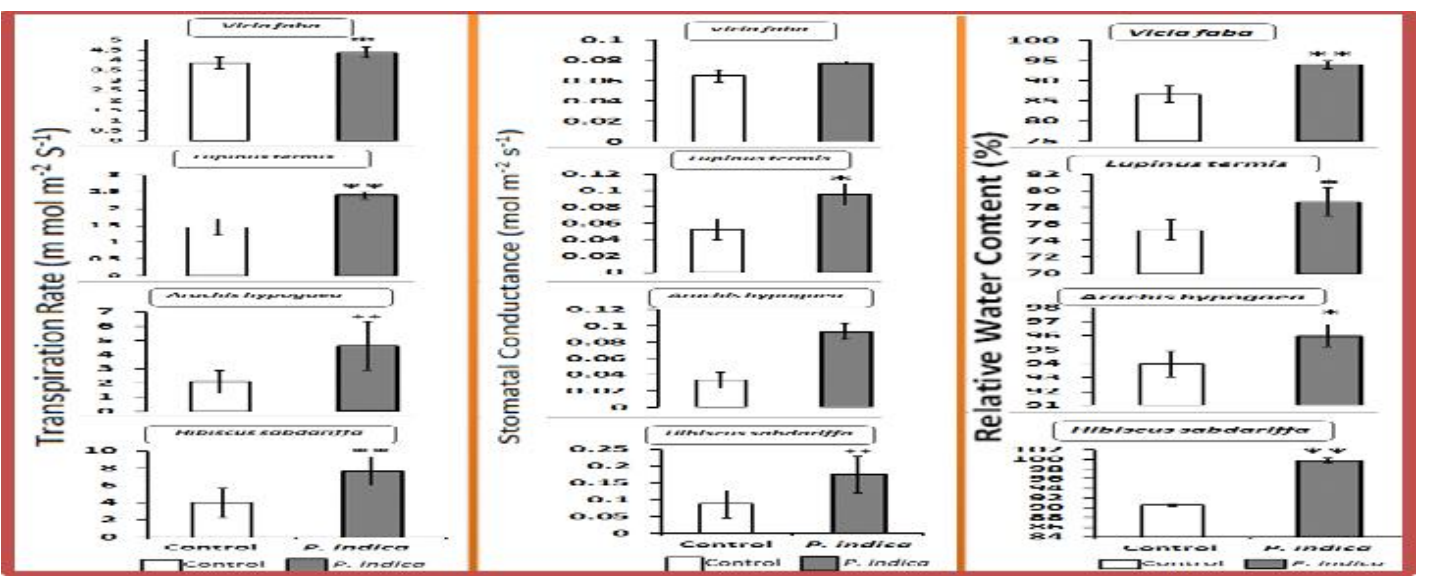

Figure 3: Effect of inoculation with $P$.indica on transpiration rate, stomatal conductance and relative water content of experimental plants. Error bar in each column equals the standard deviation from the mean. Difference is significant at $\mathrm{P}<0.05(*)$, at $\mathrm{P}<0.01(* *)$, and at $\mathrm{P}<0.001(* * *)$ according the One-Way ANOVA.

\section{Protein content and profile:}

In order to test the effect of $P$. indica on protein accumulation, the various fractions (soluble, insoluble and total) were determined (cf. Fig. 4). The soluble proteins of various tested plants exhibited higher contents in colonized plants by $P$. indica than those of non-colonized plants. Similarly, values of insoluble and total proteins of tested plants exhibited considerable variations between colonized and noncolonized plants.

To study the effect of $P$. indica on gene expression of experimental plants: $V$. faba, $L$. termis, A. hypogaea and $H$. sabdariffa. Leaves of these plants were analyzed by SDS-PAGE ( $c f$. Figs. 4). It was clear from figure 4 that some proteins were induced in colonized plants.

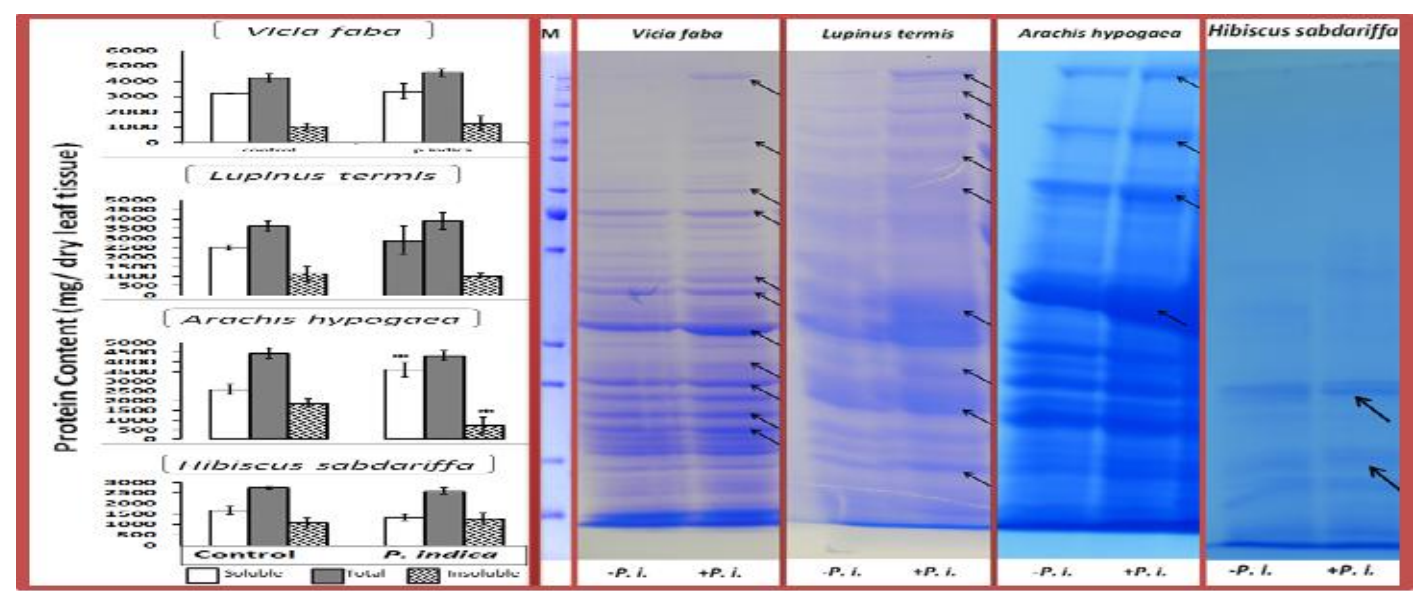

Figure 4: Effect of inoculation with $P$.indica on leaf content of protein and protein profile of experimental plants. Error bar in each column equals the standard deviation from the mean. Difference is significant at $\mathrm{P}<0.05(*)$, at $\mathrm{P}<0.01(* *)$, and at $\mathrm{P}<0.001(* * *)$ according the One-Way ANOVA.

\section{Element content:}

The results of chemical analyses to element content in dry leaves tissue for colonized plants such as sodium, calcium and potassium showed different content compared to non-colonized plants. These 
difference in element contents depended upon the element identity and plant species. Moreover, sodium content in colonized plants appeared decreasing content compered to non-colonized plants. Decreasing ratios were $16 \%, 10 \%, 13 \%$ and $20 \%$ in $V$. faba, $L$. termis, A. hypogaea and $H$. sabdariffa, respectively. Furthermore, calcium content in colonized plants was better than calcium content in non-colonized plants. Where, increasing ratios were, $25 \%, 40 \%, 30 \%$ and $14 \%$ in $V$. faba, L. termis, A. hypogaea and $H$. sabdariffa, respectively. Finally, potassium content appeared relative similarity to calcium in terms of the increasing in the content in colonized plants compered to non-colonized plants. Positive increasing percentages were $25 \%, 16 \%, 40 \%$ and $45 \%$ in $V$. faba, L. termis, A. hypogaea and H. sabdariffa, respectively (cf. Figs. 5).

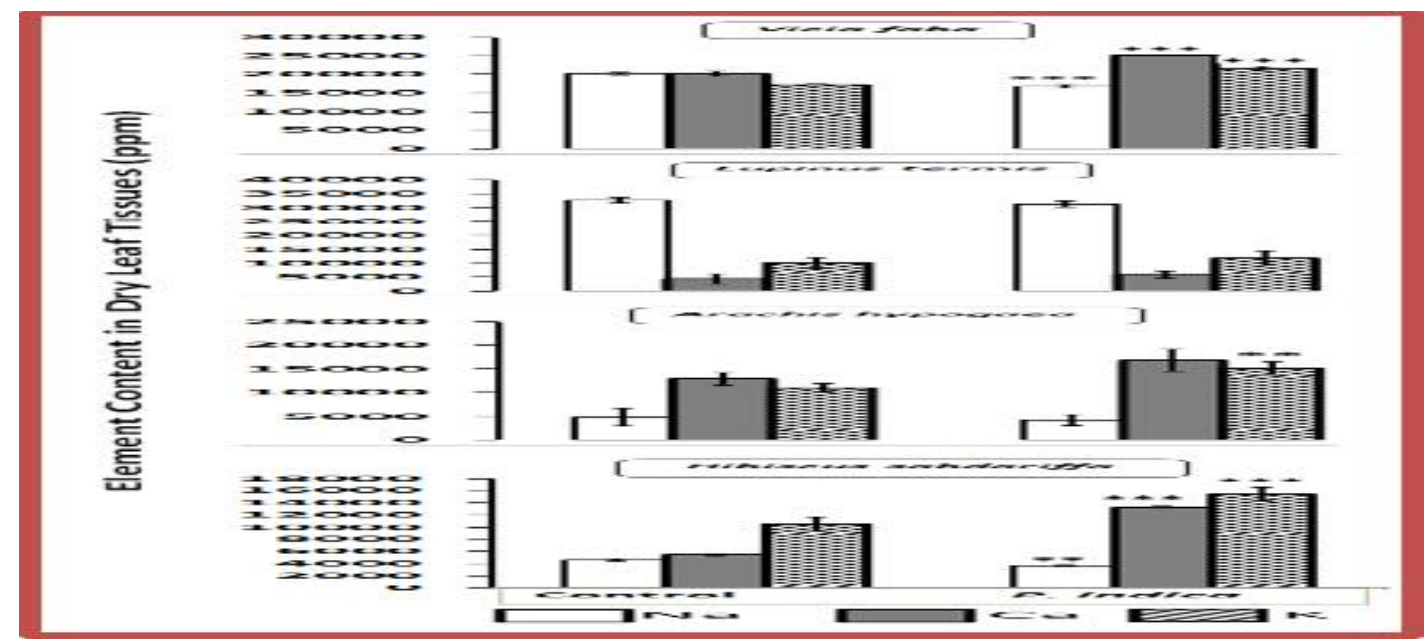

Figure 5: Effect of inoculation with $P$.indica on element content in dry leaf tissue of experimental plants. Error bar in each column equals the standard deviation from the mean. Difference is significant at $\mathrm{P}<0.05(*)$, at $\mathrm{P}<0.01(* *)$, and at $\mathrm{P}<0.001(* * *)$ according the One-Way ANOVA.

\section{Discussion}

\section{Plant growth parameters:}

In the present study, $P$. indica was axenically cultivated and applied to V. faba, L. termis, $A$. hypogaea and $H$. sabdariffa under controlled pot conditions in order to analyze its potential on growth and physiological process of the plants. We observed that $P$. indica enhanced the growth of the colonized plant as compared with the non-colonized plants which was also reported previously (Varma, et al., 1999; Peskan-Berghöfer, et al., 2004; Oelmüller R, et al.,2009; Rai M., et al., 2001; Rai M., et al., 2004; Rai M., et al., 2005; Fakhro A., et al., 2010; Achatz B., et al., 2010).

$P$. indica is a root-endophytic fungus with plant growth promoting abilities. The increasing ratios in the root fresh weight of colonized plants: V. faba, L. termis, A. hypogaea and $H$. sabdariffa were found to be $60 \%, 133 \%, 35 \%$ and $55 \%$, respectively. Furthermore, shoot biomass enhancement in colonized plants reached to $92 \%, 16 \%$ and $70 \%$ for fresh weight, in V. faba, L. termis and $A$. hypogaea, respectively. The increase of fresh weights was in some studies between 20\% and 40\% (Peskan-Berghöfer et al., 2004; Barazani et al., 2005) while it could reach in others up to 100\% (Varma et al., 1999; Waller et al., 2005; Serfling et al., 2007). Fresh weight of $P$. indica-colonized plants were, however, in the best case not more than $20 \%$ higher than in controls and reached although significant in most experiments increases of only $10 \%$. This was probably on the one hand dependent on the plant species (Druege et al., 2007; Fakhro A et al., 2010). On the other hand, conditions of inoculation (plant stage, substrate, and inoculum density) and growth clearly played an important role (Fakhro A et al., 2010).

Since $P$. indica colonizes a large variety of host plants (mono as well as dicot), it is likely that the beneficial symbiosis is based on general and not host-specific signaling events. Plant hormones might be a key to explain the broad host spectrum of $P$. indica( Schäfer P et al.,2009; Lee YC et al., 2011). Auxin for example has been proposed to be involved in $P$. indica-induced growth 
stimulation (Lee YC et al., 2011; Sirrenberg A, et al., 2007; Vadassery J, et al., 2008).

In our experiments, there was extensive branching of roots treated with fungus, which provided evidence that auxin also played a role in the $V . f a b a, L$. termis, A. hypogaea and Hibiscus sabdariffa /P. indica symbiosis.

$P$. indica colonized roots were further developed, as suggested by earlier expression of developmentally regulated genes (Waller et al., 2008). Such enhancement of root growth could be based either on fungal production of phytohormones like the auxin indole acetic acid, as shown in the interaction of $P$. indica with Arabidopsis (Sirrenberg et al., 2007) and as discussed for the effect of $P$. indica on the rooting of cuttings (Druege et al., 2007). Recent results of barley root transcriptome analysis, on the other hand, suggested a rather complex interplay of $P$. indica with the host plant, including transiently altered expression levels of gibberelic acid biosynthesis genes and abscisic acid responsive genes, but not a strong broad-scale induction of auxininduced genes in the early phases of root colonization (Schäfer et al., 2009). The molecular details of $P$. indica-induced growth early in development therefore remains to be clarified (Beate A et al., 2010). It had been reported that the fungus produces relatively high levels of cytokinins and its concentration are higher in colonized roots (Vadassery J et al., 2008). Recently, it was demonstrated that the restriction of fungal growth by ethylene signaling components was required for the beneficial interaction between Arabidopsis and P. indica ( Camehl I et al., 2010).

\section{Photosynthesis properties:}

In the present study, we observed higher photosynthetic potential and chlorophyll levels. Where Photosynthetic pigments content in leaf plant tissue appeared significant increase in colonized plants compared to non-colonized plants in all experimented plants. Where increasing ratio of total photosynthetic pigments were $21 \%$, $50 \%, 16 \%$ and $13 \%$ in cases V. faba, $L$. termis, A. hypogaea and $H$. sabdariffa, respectively. Significant increases in photosynthetic rate were recorded. These increases reach up to $28 \%, 53 \%, 50 \%$ and $46 \%$ in V. faba, L. termis, A. hypogaea and
H. sabdariffa, respectively. In barley, the observed enhanced photosynthetic rates of colonized plants (Oelmüller R, et al., 2009) contributed to this improved status. Humbeck et al. 1994 observed that $P$. indica enhanced the host plants` photosynthetic rate under low light conditions. Therefore, increased assimilation of $P$. indica colonized plants could significantly contribute to faster development and higher yield. In contrast, plants colonized by AM fungi showed photosynthetic enhancement at both low and high light intensities (Mathur and Vyas 1995; Caravaca et al., 2003), which was shown to be independent of leaf phosphate concentrations (Fay et al., 1996; Wright et al., 1998). This could indicate that the mechanism of $P$. indica influencing the rate of photosynthesis is different from AM fungi. A reason for a higher photosynthetic rate at low light could be due to the higher chlorophyll content, which would be in line with an observed darker green pigmentation of $P$. indica colonized plants up to the age of 8 weeks. Determination of relative chlorophyll content between 8 and 12 weeks in the two barley cultivars under outdoor conditions did not indicate consistently higher relative chlorophyll contents of $P$. indica colonized plants (Achatz B et al., 2010). A higher photosynthesis rate of host plants without differences in chlorophyll content was also observed in experiments analyzing the effects of AM fungi (Paradi et al., 2003). Furthermore, the intercellular $\mathrm{CO} 2$ concentration (Ci) showed nonsignificant increasing in cases $V$. faba, $L$. termis and Hibiscus sabdariffa, while there is significant increasing in case A. hypogaea in colonized plants compared to non-colonized plants.

\section{Water relation and nutrient uptake:}

Arbuscular mycorrhizal fungi enhance plant growth by increasing nutrients and water uptake, explored soil volume $100 \%$ greater (Barazani O et al., 2005; Schäfer P et al., 2009; Schäfer P et al, 2009; Lee YC et al., 2011; Sirrenberg A et al., 2007). The observed results exhibited increase in calcium and potassium content in colonized plants compared to non-colonized plants in $V$. faba, L. termis, A. hypogaea and $H$. sabdariffa.

The observed results showed transpiration rate (E) exhibited significant increase in 
colonized plants by $P$. indica. Results showed a variable increasing ratio in stomatal conductance process in colonized plants compared to non-colonized plants.

Beata A et al., 2010, suggested that increased root growth results in improved acquisition of water and nutrients in the early phase of the symbiotic interaction. This would be in line with results of Yadav et al., who detected higher phosphate contents in maize plants three weeks after $P$. indica inoculation.

Several studies are available on the impact of AMF on plants abiotic stress tolerance, suggesting that AMF play a comprehensive role in plants stress tolerance, and colonization of AMF induces a molecular signaling cascade that affects stomatal conductance, transpiration, photosynthesis, leaf dehydration, root hydration, hydraulic conductivity, growth, nutrient uptake, low weight metabolites (e.g., sugars, glycerol, amino acids, and sugar alcohols), and morphology. However, application of AMF in sustainable agriculture is limited due to unavailability of axenic culture and its host specificity, as AMF cannot colonize a group of important crop plants (Manoj K et al., 2012). The benefit of $P$. indica is its ability to be cultured in artificial culture medium, whereas other arbuscular mycorrhizal fungi, being obligate symbiont cannot be cultured in the absence of a suitable host partner (Waller F et al., 2005).

\section{Reference:}

Achatz, B., Kogel, K., Franken, P., Waller, F. (2010). Piriformospora indica mycorrhization increases grain yield by accelerating early development of barley plants. Plant Signaling \& Behavior, 5 (12): 1685-1687.

Achatz, B., von Rüden, S., Andrade, D., Neumann, E., Pons-Kühnemann, J., Franken, P., et al (2010). Root colonization by Piriformospora indica enhances grain yield in barley under diverse nutrient regimes by accelerating early plant development. Plant Soil, 333:59-70.

Barazani, O., Benderoth, M., Groten, K., Kuhlemeier, C., Baldwin, I.T. (2005). Piriformospora indica and Sebacina vermifera increase growth performance at the expense of herbivore resistance in Nicotiana attenuata. Oecologia, 146: 234-243.

Barazani, O., Benderoth, M., Groten, K., Kuhlemier, C., Baldwin, I.T. (2005). Piriformospora indica and Sebacina vermifera increase growth performance at the expense of herbivore resistance in Nicotiana attenuate. Oecologia, 146:234-43.

Camehl, I., Sherameti, I., Venus, Y., Bethke, G., Varma, A., Lee, J., et al (2010). Ethylene signalling and ethylenetargeted transcription factors are required to balance beneficial and non-beneficial traits in the symbiosis between the endophytic fungus Piriformospora indica and Arabidopsis thaliana. New Phytol, 185:1062-73.

Caravaca, F., Diaz, E., Barea, J.M., AzcónAguilar, C., Roldán, A. (2003). Photosynthetic and transpiration rates of Oleaeuropaea subsp. sylvestris and Rhamnus lycioides as affected by water deficit and mycorrhiza. Biol Plant, 46:637-639.

Drüge, U., Baltruschat, H., Franken, P. (2007). Piriformospora indica promotes adventitious root formation in cuttings. Sci Hortic, 112:422-426.

Fakhro, A., Diana, Rocío. Andrade-Linares \& Susanne von Bargen, Bandte M., Büttner, C. \& Rita, G., Schwarz, D., Franken, P. (2010). Impact of Piriformospora indica on tomato growth and on interaction with fungal and viral pathogens. Mycorrhiza, 20:191-200.

Fay, P., Mitchell, D.T., Osborne, B.A. (1996). Photosynthesis and nutrientuse efficiency of barley in response to low arbuscular mycorrhizal colonization and addition of phosphorus. New Phytol, 132:425433.

Franken, P. (2012). The plant strengthening root endophyte Piriformospora indica: potential application and the biology behind. Appl Microbiol Biotechnol, 96:1455-1464.

Glen, M., Tommerup, I.C., Bougher, N.L., O'Brien, P.A. (2002). Are Sebacinaceae common and widespread ectomycorrhizal associates of Eucalyptus species in 
Australian forests? Mycorrhiza, 12: 243-247.

Gonzalez, L., Gonzalez-Vilar, M. (2001). Determination of relative water content. In: REIGOSA, M.J. Handbook of plant ecophysiology techniques. Dordrecht: Kluwer Academic, 207-212.

Humbeck, K., Kloppstech, K., Krupinska, K. (1994). Expression of early lightinducible proteins in flag leaves of field-grown barley. Plant Physiol, 105:1217-1222.

Humphrjes, A.A. (1956). A study of meiosis in coelomic and oviducal oocytes of Triturus viridescens, with particular emphasis on the origin of spontaneous polyploidy and the effects of heat shock on the first meiotic division. J. Morphol., 99: 97-136.

Kafer, E. (1977). Meiotic and mitotic recombination in Aspergillus and its chromosomal aberrations. Advances in Genetics, 19: 33-131.

Kaldorf, M., Koch, B., Rexer, K.H., Kost, G., Varma, A. (2005). Patterns of interaction between Populus Esch5 and Piriformospora indica: a transition from mutualism to antagonism. Plant Biology 7: 210 218.

Kumar, M., Sharma, R., Jogawat, A., Singh, P., Dua, M., Gill, S.S,, Trivedi, D.K., Tuteja, N., Verma, A.K., Oelmuller, R., Johri, A.K. (2012). Piriformospora indica, A Root Endophytic Fungus, Enhances Abiotic Stress Tolerance of the Host Plant. Improving Crop Resistance to Abiotic Stress, First Edition.

Laemmli, V.K. (1970). Cleavage of structural proteins during assembly of the head of bacteriophage T4. Nature, 277: 680-685.

Lee, Y.C., Johnson, J.M., Chien, C.T., Sun, C., Cai, D., Lou, B., et al (2011). Growth promotion of Chinese cabbage and Arabidopsis by Piriformospora indica is not stimulated by mycelium-synthesized auxin. Mol. Plant-Microb Interact, 24:421-31.

Lowery, O.H., Rosebrough, N.J., Farr, A.L., Randall, R.J. (1951). protin measurement with the folin phenol reagent. J. Biol. Chem, 193: 265275.

Mathur, N., Vyas, A. (1995). Influence of VA mycorrhizae on net photosynthesis and transpiration of Ziziphus mauritiana. J Plant Physiol, 147:328-330.

Metzner, H., Rau, H., Senger, H. (1965). Unter

suchungerZursynchronisierbarkeitein zelner pigment- MangelMutanten Von Chlorella. Planta 65:186-194.

Oelmüller, R., Peškan-Berghöfer, T., Shahollari, B., Sherameti, I., Varma, A. (2005). MATH-domain containing proteins represent a novel gene family in Arabidopsis thaliana and are involved in plant/microbe interactions. Physiologia Plantarum, 124: 152-166.

Oelmüller, R., Shahollari, B., PeškanBerghöfer, T., Trebicka, A., Giong, P.H., Sherameti, I., Oudhoff, M., Venus Y, Altschmied L, Varma A (2004). Molecular analyses of the interaction between Arabidopsis roots and the growth-promoting fungus Piriformospora indica. Endocytobiosis Cell Research. 15: 504- 517.

Oelmüller, R., Sherameti, I., Tripathi, S., Varma, A. (2009). Piriformospora indica, a cultivable root endophyte with multiple biotechnological applications. Symbiosis, 49:1-17.

Paradi, I., Bratek, Z., Lang, F. (2003). Influence of arbuscular mycorrhiza and phosphorus supply on polyamine content, growth and photosynthesis of Plantago lanceolata. Biol Plantarum, 46:563-569.

Peškan-Berghöfer, T., Shahollari, B., Giang, P.H., Hehl, S., Markert, C., Blanke, V., Varma, A.K., Oelmüller, R. (2004). Association of Piriformospora indica with Arabidopsis thaliana roots represents a novel system to study beneficial plant-microbe interactions and involves early plant protein modifications in the endoplasmatic reticulum and at the plasma membrane. Physiologia Plantarum 122: 465-477. 
Pham, G.H., Kumari, R., Singh, A.N., Sachdev, M., Prasad, R., Kaldorf, M., Buscot, F., Oelmüller, R., Peškan, T., Weiss, M., Hampp, R., Varma, A. (2004a). Axenic cultures of Piriformospora indica. In: Plant Surface Microbiology. Varma, A., Abbott, L., Werner, D., and Hampp, R., eds. Springer-Verlag, Germany, pp. 593-616.

Pham, G.H., Singh, A.N., Malla, R., Kumari, R., Prasad, R., Sachdev, M., Rexer, K.H., Kost, G., Luis, P., Kaldorf, M., Buscot, F., Herrmann, S., Peškan, T., Oelmüller, R., Saxena, A.K., Declerck, S., Mittag, M., Stabentheiner, E., Hehl, S., Varma, A. (2004b). Interaction of Piriformospora indica with diverse microorganisms and plants. In: Plant Surface Microbiology. Varma, A., Abbott, L., Werner, D., and Hampp, R., eds. Springer-Verlag, New York, pp. 237-265.

Rai, M., Acharya, D., Singh, A., Varma, A. (2001). Positive growth responses of the medicinal plants Spilanthes calva and Withania somnifera to inoculation by Piriformospora indica in a field trial. Mycorrhiza, 11:123-8.

Rai, M.K., Varma, A., Pandey, A.K. (2004). Antifungal potential of Spilanthes calva after inoculation of Piriformospora indica. Mycoses; 47:479-81.

Rai, M.K., Varma, A. (2005). Arbuscular mycorrhizae-like biotechnological potential of Piriformospora indica, which promotes the growth of Adhatoda vasica. Electron $\mathbf{J}$ Biotechnol , 8:107-12.

Sahay, N.S., Varma, A. (1999). Piriformospora indica: a new biological hardening tool for micropropagated plants. FEMS Microbiological Letters, 181: 297302.

Schäfer, P., Pfith, S., Voll, L.M., Zajic, D., Chandler, P.M., Waller, F., et al (2009). Phytohormones in plant rootPiriformospora indica mutualism. Plant Signal Behav; 4:669-71.

Selosse, M.A., Bauer, R., Moyersoen, B. (2002a). Basal hymenomycetes belonging to the Sebacinaceae are ectomycorrhizal on temperate deciduous trees. New Phytologist, 155: 183-195.

Selosse, M.A., Weiss, M., Jany, J.L., Tillier, A. (2002b). Communities and populations of sebacinoid basidiomycetes associated with the achlorophyllous orchid Neottia nidus-avis (L.) L.C.M. Rich. and neighbouring tree ectomycorrhizae. Molecular Ecology, 11: 1831-1844.

Serfling, A., Wirsel, S.G.R., Lind, V., Deising, H.B. (2007). Performance of the biocontrol fungus Piriformospora indica on wheat under greenhouse and field conditions. Phytopathology, 97: 523-531.

Shahollari, B., Vadassery, J., Varma, A., Oelmüller, R. (2007a). A leucinerich repeat protein is required for growth promotion and enhanced seed production mediated by the endophytic fungus Piriformospora indica in Arabidopsis thaliana. Plant Journal, 50: 1-13.

Shahollari, B., Varma, A., Oelmüller, R. (2005). Expression of a receptor kinase in Arabidopsis roots is stimulated by the basidiomycete Piriformospora indica and the protein accumulates in Triton X-100 insoluble plasma membrane microdomains. Journal of Plant Physiology, 162: 945-958.

Sherameti, I., Shahollari, B., Venus, Y., Altschmied, L., Varma, A., Oelmüller, R. (2005). The endophytic fungus Piriformospora indica stimulates the expression of nitrate reductase and the starchdegrading enzyme glucan-water dikinase in tobacco and Arabidopsis roots through a homeodomain transcription factor which binds to a conserved motif in their promoters. Journal of Biological Chemistry, 280: 2641-2647.

Sherameti, I., Tripathi, S., Varma, A., Oelmüller, R. (2008a). The rootcolonizing endophyte Piriformospora indica confers drought tolerance in Arabidopsis by stimulating the expression of drought stress-related genes in leaves. 
Molecular Plant- Microbe Interaction, 21: 799-807.

Sherameti, I., Venus, Y., Drzewiecki, C., Tripathi, S., Dan, V.M., Nitz, I., Varma, A., Grundler, F.M., Oelmüller, R. (2008b). PYK10, a $\beta$ glucosidase located in the endoplasmatic reticulum, is crucial for the beneficial interaction between Arabidopsis thaliana and the endophytic fungus Piriformospora indica. Plant Journal, 54: 428-439.

Sirrenberg, A., Göbel, C., Grond, S., Czempinski, N., Ratzinger, A., Karlovsky, P., et al (2007). Piriformospora indica affects plant growth by auxin production. Physiol Plant, 131:581-9.

Urban, A., Weiss, M., Bauer, R. (2003). Ectomycorrhizas involving sebacinoid mycobionts. Mycological Research, 107: 3-14.

Vadassery, J., Ranf, S., Mithöfer, A., Mazars, C., Scheel, D., Lee, J., Oelmüller, R. (2009a). A cell wall extract from the endophytic fungus Piriformospora indica promotes growth of Arabidopsis seedlings and induces intracellular calcium elevation in roots. Plant Journal, 59: 193-206.

Vadassery, J., Ritter, C., Venus, Y., Camehl, I., Varma, A., Shahollari, B., et al (2008). The role of auxins and cytokinins in the mutualistic interaction between Arabidopsis and Piriformospora indica. Mol Plant Microbe Interact, 21:1371-83.

Vadassery, J., Ritter, C., Venus, Y., Camehl, I., Varma, A., Shahollari, B., Novák, O., Strnad, M., Ludwig-Müller, J., Oelmüller, R. (2008a). The role of auxins and cytokinins in the mutualistic interaction between Arabidopsis and Piriformospora indica. Molecular Plant-Microbe Interaction, 21: 1371-1383.

Vadassery, J., Tripathi, S., Prasad, R., Varma, A., Oelmüller, R. (2009b). Monodehydroascorbate reductase 2 and dehydroascorbate reductase 5 are crucial for a mutualistic interaction between Piriformospora indica and Arabidopsis. Journal of Plant Physiology, 166: 1263-1274.
Varma, A., Singh, A., Sudha Sahay, N., Sharma, J., Roy, A., Kumari, M., Rana, D., Thakran, S., Deka, D., Bharti, K., Franken, P., Hurek, T., Blechert, O., Rexer, K.H., Kost, G., Hahn, A., Hock, B., Maier, W., Walter, M., Strack, D., Kranner, I. (2001). Piriformospora indica: A cultivable mycorrhiza- like endosymbiotic fungus. In: Mycota IX. Springer Series, Germany, 123150.

Varma, A., Verma, S., Sudha Sahay, N.S., Bütehorn, B., Franken, P. (1999). Piriformospora indica, a cultivable plant growth promoting root endophyte. Applied and Environmental Microbiology 65: 2741-2744.

Verma, S.A., Varma, A., Rexer, K.H., Hassel, A., Kost, G., Sarbhoy, A., Bisen, P., Bütehorn, B., Franken, P. (1998). Piriformospora indica, gen. et sp. nov., a new root-colonizing fungus. Mycologia, 90: 898-905.

Waller, F., Achatz, B., Baltruschat, H., Fodor, J., Becker, K., Fischer, M., Heier, T., Hückelhoven, R., Neumann, C., von Wettstein, D., Franken, P., Kogel, K.H. (2005). The endophytic fungus Piriformospora indica reprograms barley to saltstress tolerance, disease resistance, and higher yield. Proc Natl Acad Sci USA, 102:13386-13391.

Waller, F., Achatz, B., Baltruschat, H., Fodor, J., Becker, K., Fischer, M., Heier, T., Hückelhoven, R., Neumann, C., Wettstein, D., Franken, P., Kogel, K.H. (2005). The endophytic fungus Piriformospora indica reprograms barley to saltstress tolerance, disease resistance, and higher yield. Proceedings of the National Academy of Sciences USA, 102: 13386-13391.

Waller, F., Mukherjee, K., Deshmukh, S.D., Achatz, B., Sharma, M., Schäfer, P., Kogel, K.H. (2008). Systemic and local modulation of plant responses by Piriformospora indica and related Sebacinales species. Journal of Plant Physiology, 165: 60-70.

Weiss, M., Selosse, M.A., Rexer, K.H., Urban, A., Oberwinkler, F. (2004). 
Sebacinales: a hitherto overlooked cosm of hetero basidiomycetes with a broad mycorrhizal potential. Mycological Research, 108: 10031010.

Wright, D.P., Scholes, J.D., Read, D.J. (1998). Effects of VA mycorrhizal colonisation on photosynthesis and biomass production of Trifolium repens L. Plant Cell Environ, 21:209-216.

Yadav, V., Kumar, M., Deep, D.K., Kumar, H., Sharma, R., Tripathi, T., et al (2010). A phosphate transporter from the root endophytic fungus Piriformospora indica plays a role in phosphate transport to the host plant. J Biol Chem, 285:26532-44.

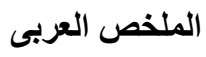

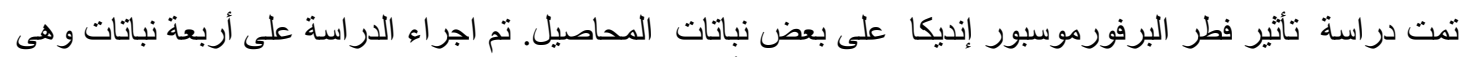

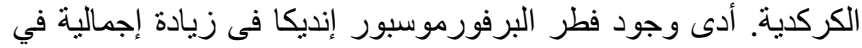

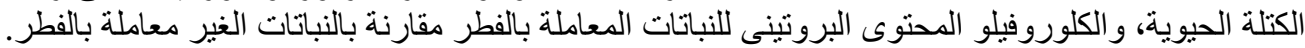
تعزيز العلاقات المائية وامتصاص العناصى العروئرالمعدنية في جميع أنواع النباتات المختبرة. 